\title{
Challenges and perspectives in the treatment of patients with haemophilia in Brasil
}

\author{
Vanessa Girotto Guedes 1 \\ Sylvia Thomas ${ }^{1}$ \\ Patrick Alexander Wachholz ${ }^{2}$ \\ Sergio Augusto Lopes Souza ${ }^{1}$
}

1. Rio de Janeiro Federal University (UFRJ), Nuclear Medicine Department, Rio de Janeiro - RJ, Brasil 2. São Paulo State University (UNESP), Faculty of Medicine, Botucatu - SP, Brasil

http://dx.doi.org/10.1590/1806-9282.64.10.872

Dear Editor,

Haemophilia affects more than 184,000 people worldwide. ${ }^{1}$ Despite increasing advances, it is still associated with a high prevalence of disabilities, posing an economic burden to individuals and health systems. ${ }^{2}$ Over the last decades, significant therapeutic improvements have been achieved, including advances in blood safety, prophylaxis with coagulation factor concentrates (CFC), treatment with inhibitors of coagulation factors, orthopedic surgeries to correct limbs deformities and long-acting CFC. ${ }^{2,3}$ It is anticipated that new compounds which could be applied subcutaneously and gene therapy will be of benefit to patients with hemophilia (PWH) in the future. ${ }^{4}$

Without prophylactic treatment, approximately $80 \%$ of all bleedings in PWH occur inside joints (haemarthroses), mainly ankles, knees and elbows. ${ }^{5}$ Although prophylaxis with CFC for children and adults with severe hemophilia is recognized to prevent hemophilic arthropathy, ${ }^{6}$ it is not available to all PWH. Accordingly, it is estimated that approximate- ly $75 \%$ of PWH worldwide ( 350,000) are not regularly treated, if at all. ${ }^{4}$

It is known that CFC accounts for up to $80 \%$ of the overall cost of hemophilia treatment ${ }^{2}$ presenting a barrier to patient care in developing countries. Indeed, hemophilia health care costs in the United States are approximately $\$ 140,000$ USD/year; ${ }^{7}$ in patients with inhibitors to factor VIII, costs of treatment can be 4.8 times higher. $^{7}$

According to the last Annual Global Survey (Table 1), Brazil has the fourth highest number of registered PWH $(\mathrm{n}=12,119){ }^{1}{ }^{1}$ The Brazilian federal government provides $100 \%$ of CFC to these patients; up to $77 \%$ of $\mathrm{PWH}$ under 18 years of age and $31 \%$ for those over 18 benefit from prophylaxis, although this was only available from late 2011. ${ }^{1}$ The Brazilian Unified Health System (SUS), which is part of the 1988 National Constitution, acknowledges that health is a fundamental right of the citizen, which must be guaranteed by the State through a set of 
governmental policies and actions, with community participation (social control).

According to the SUS principles of hierarchy and decentralization, in this context, the roles of the Ministry of Health (MoH) are purchasing the CFCs and establishing national policies and guidelines, while the states and municipalities are responsible for the multidisciplinary care of $\mathrm{PWH}$.

The PWH society encompasses non-governmental organizations (NOG), as well as individuals with inherited bleeding disorders and their relatives. The Brazilian Federation of Haemophilia (FBH), with its regional chapters, represents Brazil in the World
Federation of Hemophilia (WFH); they play a key role in advocating for $\mathrm{PWH}$.

The WFH (through FBH) has been providing the $\mathrm{MoH}$ with technical, accessible and credible information on products for the treatment of bleeding disorders and their costs, as practiced in other countries, thus supporting better decision-making by the country. It also conducts national and international meetings as well as scientific congresses, which are important to the development of public policies. Moreover, FBH is represented on the Coagulopathy Committee, the technical arm of the $\mathrm{MoH}$ in the Bleeding Disorders area. This committee, among

TABLE 1. POPULATION DATA FROM THE FOUR COUNTRIES WITH THE LARGEST NUMBER OF PEOPLE WITH HEMOPHILIA WORLDWIDE, ACCORDING TO THE REPORT ON THE ANNUAL GLOBAL SURVEY 2016 FROM THE WORLD FEDERATION OF HEMOPHILIA, 2017.

\begin{tabular}{|c|c|c|c|c|c|c|c|c|}
\hline Country & Population & $\begin{array}{l}\text { People with } \\
\text { hemophilia }\end{array}$ & \multicolumn{2}{|l|}{ Haemophilia A } & $\begin{array}{l}\text { Mean per } \\
\text { capita factor } \\
\text { VIII use }^{*}\end{array}$ & \multicolumn{2}{|l|}{ Haemophilia B } & $\begin{array}{l}\text { Mean per } \\
\text { capita factor } \\
\text { IX use }^{*}\end{array}$ \\
\hline \multirow[t]{7}{*}{ India } & \multirow[t]{7}{*}{$1,324,171,354$} & \multirow{7}{*}{$\begin{array}{l}\text { 18,353 } \\
\text { (756 type } \\
\text { unknown) }\end{array}$} & Age 0 to 4 & $2 \%$ & \multirow{7}{*}{$\begin{array}{l}0,105 \\
\text { (including } \\
\text { humanitarian } \\
\text { aid) }\end{array}$} & Age 0 to 4 & $2 \%$ & \multirow[t]{7}{*}{0,002} \\
\hline & & & Age 5 to 13 & $15 \%$ & & Age 5 to 13 & $13 \%$ & \\
\hline & & & Age 14 to 18 & $11 \%$ & & Age 14 to 18 & $13 \%$ & \\
\hline & & & Age 19 to 44 & $36 \%$ & & Age 19 to 44 & $41 \%$ & \\
\hline & & & Age $\geq 45$ & $7 \%$ & & Age $\geq 45$ & $9 \%$ & \\
\hline & & & Age not known & $28 \%$ & & Age not known & $22 \%$ & \\
\hline & & & Total & 15,218 & & Total & 2,379 & \\
\hline \multirow{7}{*}{$\begin{array}{l}\text { United } \\
\text { States }\end{array}$} & \multirow[t]{7}{*}{$323,127,513$} & \multirow[t]{7}{*}{16,949} & Age 0 to 4 & $9 \%$ & \multirow[t]{7}{*}{9,532} & Age 0 to 4 & $9 \%$ & \multirow[t]{7}{*}{1,656} \\
\hline & & & Age 5 to 13 & $25 \%$ & & Age 5 to 13 & $24 \%$ & \\
\hline & & & Age 14 to 18 & $13 \%$ & & Age 14 to 18 & $11 \%$ & \\
\hline & & & Age 19 to 44 & $33 \%$ & & Age 19 to 44 & $29 \%$ & \\
\hline & & & Age $\geq 45$ & $20 \%$ & & Age $\geq 45$ & $26 \%$ & \\
\hline & & & Age not known & $0 \%$ & & Age not known & $0 \%$ & \\
\hline & & & Total & 12,996 & & Total & 3,953 & \\
\hline \multirow[t]{7}{*}{ China } & \multirow[t]{7}{*}{$1,378,665,000$} & \multirow[t]{7}{*}{14,390} & Age 0 to 4 & $3 \%$ & \multirow{7}{*}{$\begin{array}{l}\text { Data not } \\
\text { available }\end{array}$} & Age 0 to 4 & $3 \%$ & \multirow{7}{*}{$\begin{array}{l}\text { Data not } \\
\text { available }\end{array}$} \\
\hline & & & Age 5 to 13 & $20 \%$ & & Age 5 to 13 & $4 \%$ & \\
\hline & & & Age 14 to 18 & $13 \%$ & & Age 14 to 18 & $26 \%$ & \\
\hline & & & Age 19 to 44 & $49 \%$ & & Age 19 to 44 & $50 \%$ & \\
\hline & & & Age $\geq 45$ & $15 \%$ & & Age $\geq 45$ & $27 \%$ & \\
\hline & & & Age not known & $1 \%$ & & Age not known & $1 \%$ & \\
\hline & & & Total & 12,533 & & Total & 1,857 & \\
\hline \multirow[t]{7}{*}{ Brazil } & \multirow[t]{7}{*}{$207,652,865$} & \multirow[t]{7}{*}{12,119} & Age 0 to 4 & $5 \%$ & \multirow[t]{7}{*}{3,556} & Age 0 to 4 & $5 \%$ & \multirow[t]{7}{*}{0,578} \\
\hline & & & Age 5 to 13 & $16 \%$ & & Age 5 to 13 & $15 \%$ & \\
\hline & & & Age 14 to 18 & $11 \%$ & & Age 14 to 18 & $13 \%$ & \\
\hline & & & Age 19 to 44 & $49 \%$ & & Age 19 to 44 & $47 \%$ & \\
\hline & & & Age $\geq 45$ & $18 \%$ & & Age $\geq 45$ & $19 \%$ & \\
\hline & & & Age not known & 0 & & Age not known & 0 & \\
\hline & & & Total & 10,123 & & Total & 1,996 & \\
\hline
\end{tabular}

Adapted from the data available on the Report on the Annual Global Survey 2016 (World Federation of Hemophilia, 2017). * The number of IU/capita is different in each region. The World Federation of Hemophilia has established that one international unit (IU) of FVIII clotting factor concentrate per capita should be the target minimum for countries wishing to achieve survival for the hemophilia population. Higher levels would be required to preserve joint function or achieve a quality of life equivalent to an individual without hemophilia. Only countries that completed the 2016 questionnaire were included in the report. 


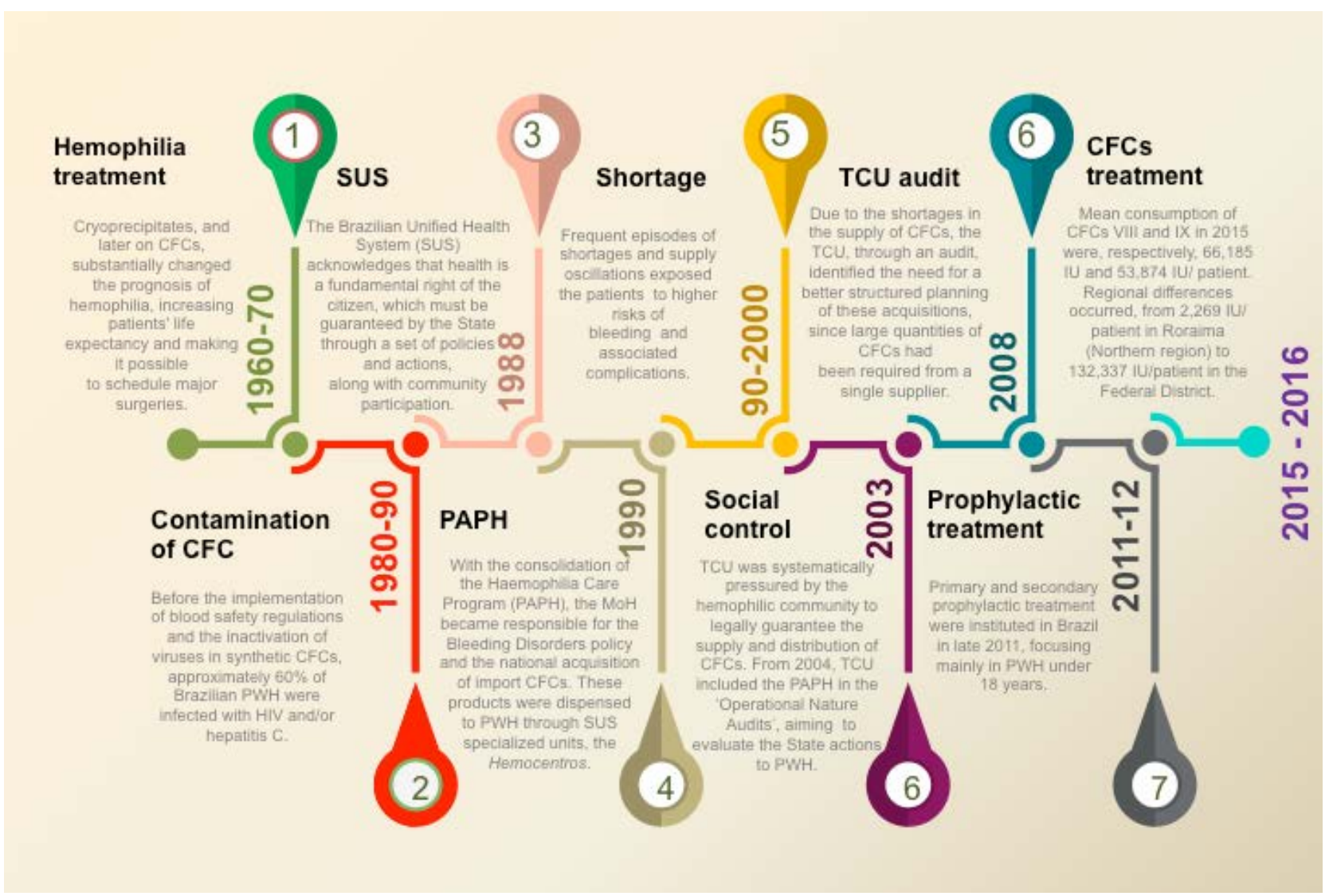

FIGURE 1

other responsibilities, helps the $\mathrm{MoH}$ to formulate public policies and develop technical guidelines.

Nevertheless, it is recognized that recently other NOGs and individuals have also pledged health rights through judicial institutions, such as the Public Chambers of Attorney and the Brazilian Government Agency for Law Enforcement (in Brazil, Ministério Público).

Frequently, global care to PWH has been jeopardized by oscillations in CFC supply, exposing the patients to risks of bleeding and associated complications. The increased dismantling of the SUS and scrapping of public services, especially at state level, but also affecting the municipal and federal scope, is a challenge which can only be overcome through close cooperation with hemophilia patient societies and those that treat hemophilia. The infographic in Figure 1 presents a brief historical description of the achievements and obstacles of PWH in Brazil. ${ }^{8,9}$

Brazil also has some unmet needs, such as the provision of faster and easier access to the most often necessary orthopedic surgeries and to hemophil- ia laboratory diagnosis in some centers. A more organized health system should also educate the patients and their families so that they can take advantage of the treatment offered by the Haemophilia Centres (in Brazil, Hemocentros). Indeed, despite an appropriate prescription, 54\% of patients do not understand and correctly adhere to the prophylaxis prescribed by healthcare practitioners. ${ }^{10}$

Although the benefits of prophylaxis are well established, this treatment is not available for all Brazilian $\mathrm{PWH}$, and in many cases, it is not able to control the progression to hemophilic arthropathy. Considering the burden that chronic pain adds to the quality of life and daily life activities in $\mathrm{PWH}$, the establishment of evidence-based guidelines for the evaluation and treatment of these complications is vital. When looking forward in healthcare provision, it is essential to prepare for the incorporation and application of new upcoming technologies, as well as to reduce the stigma associated with hemophilia in the general population, further educating patients, family members and non-specialist medical professionals about the disease. 


\section{REFERENCES}

1. World Federation of Hemophilia. Report on the Annual Global Survey 2016 [Internet]. World Federation of Hemophilia; 2017 [cited 2017 Nov 5]. Available from: http://www1.wfh.org/publications/files/pdf-1690.pdf

2. Chen SL. Economic costs of hemophilia and the impact of prophylactic treatment on patient management. Am J Manag Care. 2016;22(5 Suppl):s126-33.

3. Curtis R, Baker J, Riske B, Ullman M, Niu X, Norton K, et al. Young adults with hemophilia in the U.S.: demographics, comorbidities, and health status. Am J Hematol. 2015;90(Suppl 2):S11-6.

4. Arruda VR, Doshi BS, Samelson-Jones BJ. Novel approaches to hemophilia therapy: successes and challenges. Blood. 2017;130(21):2251-6.

5. Peyvandi F, Jayandharan G, Chandy M, Srivastava A, Nakaya SM, Johnson M], et al. Genetic diagnosis of haemophilia and other inherited bleeding disorders. Haemophilia. 2006;12(Suppl 3):82-9.

6. Hartmann I, Croteau SE. 2017 Clinical trials update: innovations in hemophilia therapy. Am J Hematol. 2016;91(12):1252-60.

7. Guh S, Grosse SD, McAlister S, Kessler CM, Soucie JM. Health care expen- ditures for Medicaid-covered males with haemophilia in the United States, 2008. Haemophilia. 2012;18(2):276-83.

8. Ministério da Saúde. Perfil das coagulopatias hereditárias no Brasil : 2015 [Internet]. Ministério da Saúde, Secretaria de Atenção à Saúde, Departamento de Atenção Especializada e Temática.; 2017 [cited 2017 Nov 1]. Available from: http://bvsms.saude.gov.br/bvs/publicacoes/perfil_coagulopatias_hereditarias_brasil_2015.pdf

9. Santos CS, Coutinho CM, Porto MG, Gonçalves PG. Relatório de auditoria de natureza operacional na ação atenção aos pacientes portadores de coagulopatias (6142) [Internet]. p. 75. Report No.: 016.415/2006-5. Brasília: Tribunal de Contas da União; 2007 [cited 2017 Nov 1] Available from: http://portal.tcu.gov.br/lumis/portal/file/fileDownload.jsp?inline=1\&fileld =8A8182A14D6E85DD014D732742567006

10. Guedes VG. Avaliação da adesão ao tratamento profilático na hemofilia: estudo transversal no interior do Estado de São Paulo (Brasil) [Dissertação de mestrado]. Botucatu: Universidade Estadual Paulista "Júlio de Mesquita Filho", Faculdade de Medicina de Botucatu; 2016 [cited 2017 Oct 23]. Available from: https://repositorio.unesp.br/handle/11449/144323 